\title{
THE CITIZEN AS A SOURCE OF INFORMATION: A CASE STUDY OF JORNAL DA TARDE, RTP
}

\author{
Inês Mendes \& Raquel Martins
}

\begin{abstract}
Indispensable to news production, sources of information are complex and provide an interesting case review. Without them a journalist's work would be next to impossible to perform since those sources are able to reinforce and give credibility to the news. In a time when the citizen's participation in public service media is gaining more and more importance, this study aims to understand the kind of representation and prominence given to the citizen in the Portuguese television Public Service. In addition to understanding the presence of the citizen in Jornal da Tarde, RTP (Radio e Televisão de Portugal) the goal is to make a connection between the role of the Portuguese television public service and the need, or not, to call upon non-official voices to support the credibility and even the veracity of the topic in hand. In which topics the citizen's voice is more present and which testimonials are more sought after by RTP are some of the topics under discussion. In order to do that - identify the news in which the citizen's voice was used and to find answers to the given question - a content analysis of 21 broadcasts of Jornal da Tarde was performed.
\end{abstract}

Keywords

Citizen; public service; sources of information; gender

\section{INTRODUCTION}

The aim of this study consists in understanding the role the citizen plays in public service news by reflecting upon the importance he assumes in the journalist's work and by recognizing the need to analyse its presence in information programmes. Hence, in order to understand how meaningful the citizen participation is to the journalistic information and what kind of added value the citizen brings to the understanding of a certain topic, a cross-reference must be made between the role played by the sources of information and the one pertaining to the public service.

Sources are an asset to the journalists as journalism wouldn't exist without them. No matter the kind of testimonial they give, above all, they provide information. Citizens are newscast viewers, but they are also establishing themselves as sources of information, since, most of the time, they are eye witnesses or key players in certain events. Their importance as sources is, therefore, obvious but citizens are also the core of democracy: public policies are addressed to them and their participation in the democratic regime is crucial. Far more crucial since, nowadays, people seem to have been progressively drifting apart from democracy (as proven by the high abstention rate in recent elections) and there is the need to reconnect and re-engage people to democracy and restore its legitimacy. Simultaneously, public service obligations regarding plurality and citizenship 
have raised concerns about the need, or not, to rely on the citizens. As a public service channel, does RTP have a duty to give citizens a loud voice?

Consequently, by recognizing the importance of the citizen in the news setting, the aim is to understand how the citizens leave their mark and what their role in televised information is. Therefore, the starting point and what this study aims to clarify is "What is extent of the citizen's presence in Jornal da Tarde and what role does he play in it?"

To answer that question, an observation was made into Jornal da Tarde, one of RTP's news programmes, for three separate weeks, focusing on the citizen, more specifically, on its role as a source of information. Who he is, what his role is and what he conveys are the aspects under analysis.

\section{SOURCES OF INFORMATION}

They are a well-studied subject in the area of Journalism and essential to the profession as they help giving credibility to the work a journalist develops. Who are, then, the sources of information?

Sources are people, groups, social institutions or discourses - speeches, documents, and data - prepared, built and left by them. The sources refer to social positions and relations, to interests and points of view, to temporally situated locations. In short, the sources to which journalists resort or look for are interested parties, which means, implicated in determined tactics and strategies. (Pinto, 2000, p. 278)

Key to the practice of journalism, sources of information are the greatest asset of a journalist when the time comes to disclose information. They are, after all, "an unavoidable step in the news making process that, every day, imposes renewable obstacles to the journalists" (Lopes, 2000, p. 340). The relationship between journalists and their sources is, mainly, a negotiated relationship. Berkowitz states that journalists and sources "hope to achieve their goals and maintain their organizational and societal status" (Berkowitz, 2009, p. 103).

To journalists, sources are, first and foremost, at the heart of the information. Journalists want new information, they want the source to be able to confirm or deny something, to provide further clarification, ideas, debates, recommendations and, above all, to do that with credibility and legitimacy (Pinto, 2000).

Due to this interest in the sources and thanks to the recognition of its crucial importance in a journalist's activity, these professionals have, moreover, safeguarded the right to use them. In the Portuguese Journalist's Statute (Law no. 1/99), article 6 (b), the journalist is entitled to have access to sources of information. Public administration bodies and companies that, somehow, pursue public interests guarantee the right of access to sources of information to journalists. If they refuse a journalist's rightful access to the sources "administrative or contentious means can be used" against them (paragraph 4 of article 8 of the Journalist's Statute). 
Nonetheless, at the same time journalists have rights, they also have some obligations to comply to:

To treat every actor the same; not to look for information with the purpose of, in a gratuitous manner, intruding into or disrupting somebody's private life on behalf of an increasingly popular sensationalism; to always identify the one who provides the information; to respect the adversarial principle. (Lopes, 2000, p. 340)

Furthermore, although the journalist may choose not to identify his source, due to his right to professional secrecy, it is provided by law that a judge may require the court to order the source to speak or testify if the exemption is found to be illegitimate (paragraph 2 of article 135 of the Portuguese Code of Criminal Procedure).

There are many categorizations of types of sources. Aldo Schmitz recognizes official, business, institutional, individual, testimonial, specialized, and reference sources. Yet, we are going to explore and focus on the one that sees the 'ordinary citizen' as a news source. According to this author "the individual source represents itself. It can be an ordinary person, a political, cultural or artistic personality or an independent professional, as long as he doesn't speak for an organization or social entity" (Schmitz, 2011, p. 10). Chaparro (quoted in Schmitz, 2001) considers these sources as informal because they assign more humanity to the news.

"The individual source notably emerges as a victim, a complaining citizen or a witness" (Charaudeu quoted in Schmitz, 2011, p. 10). This type of sources is ultimately used for the purpose of "giving context to an information in everyday life" (Schmitz, 2011, p. 11).

\section{THE CITIZEN IN THE PUBLIC SERVICE BROADCASTING}

The presence of an audience is fundamental to ensure that the Public Service broadcasting respects its own principles. Manuel Pinto argues that "a public service that exists without the active participation of the audience is a contradiction" (Pinto, 2005, p. 49).

Defined by the principles of public service, RTP is subject to a series of provisions that regulate its performance and ensure its proper operation. These provisions commit the station with the audience, taking into account the obligations and duties that are bestowed on RTP, and favour the Portuguese culture.

Such provisions can be found in the radio and television public service's Concession Contract that defines aspects pertaining to the principles, purposes, obligations and objectives of the public service. Taking a closer look to the items that focus on the citizen as a source of information, one realizes that there is, at least apparently, a concern with the audience incorporation in the news. Above all because there is, hereby, the need to "ensure that various strands of opinion can be expressed and contrasted".

The public service should constitute a reference to the population and be based on an offer that ensures universal access, acting as a factor of cohesion and integration to all individuals, groups and social communities; 
it should guarantee the impartiality and independence of information and comments; spread innovative and diverse audiovisual content, in line with high ethical and quality standards; and establish itself as a plural discussion forum and a vehicle for the promotion of the citizens' democratic participation, as well for the audiovisual creation and production, by ensuring that the diversity of the European and cultural heritage is disseminated. (clause BB of the Concession Contract)

Citizen participation should be, according to Manuel Pinto, inherent to the public service, "wherefore this service can only be entirely justified when and as far as it relies on them [citizens] in every step and aspect" (Pinto, 2005, p. 53).

The coverage of cultural events and national interest displays is also a mandatory prerequisite and it shows concern in taking into account the Portuguese people's interests and in, even if indirectly, including them in the news broadcast. "To promote public access to Portuguese cultural events and guarantee appropriate news coverage thereof" and "to provide independent, accurate, contextualised, pluralist and open to refutation information ensuring news coverage of the major national and international events", are, therefore, some of the obligations to which the Portuguese Public Service must comply (paragraph 2 (b) (c) of Provision 6 of the Concession Contract).

As a matter of fact, the media use citizens' testimonials and the viewer's participation in television programmes as assets to secure ratings (Moreno quoted in Lopes, Ribeiro \& Neto, 2014, p. 121), which, ultimately, highlights the importance that the 'ordinary citizen' has in the news and in their treatment.

Actually, the presence of citizens in TV news coverage has increased. Since 2003, "it is not unusual to find five, six, or even more members of the public in one item" (Pantti \& Husslage, 2009, p. 88).

This presence of the citizen in the news may be interpreted as a democratic development, showing that the journalism, now, wants to display the citizen's opinion and promote his involvement in society (McNair \& Gans quoted in Pantti \& Husslage, 2009). An idea also sustained by Correia that, paraphrasing Pauly, emphasizes: "Journalism's first task, by which it can survive as a viable institution in the public arena, is to take the responsibility in promoting public dialogue on subjects that are cause of a common concern to a democratic audience" (Correia, 2012, p. 61).

And the importance of these citizens in the news has been seemingly acknowledged. Those who speak up shape the way the addressed issues are perceived and show, at the same time, what kind of opinions the society has (Ross quoted in Pantti \&Husslage, 2009). João Carlos Correia also reports that "the citizens are called to act as such, whenever the problems are recognized as of everyday life" (Correia, 2012, p. 56). Thus, the citizens have a pivotal role as an important source of information to the journalists (De Keyser, Raymaeckers \& Paulussen, 2011)'

' The authors interviewed Belgian journalists for their research, De Keyser, Raymaeckers and Paulussen (2001) established that $45,1 \%$ of the journalists claimed that citizens were important our very important sources of information. 
However, in regard to their access to the news service, the citizens may fit into a category Traquina (2002, p. 113) calls "disruptive access", that is to say, they are part of the news when something out of the ordinary and that concerns them happens. "Those less powerful disrupt the social world with the intention of altering the way events are normally produced (...). Those activities represent, in a way, 'anti-routine' events" (Molotch \& Lester quoted in Traquina, 2002, p. 113). The presence of an 'ordinary citizen' in the news process is, then, portrayed as something unusual and non-routine.

Whereas institutional sources are used to provide specialized information about a certain subject, citizens' words report their own experiences, perceptions and reactions (Carpentier, Leurdik \& Zelizer quoted in Pantti \& Husslage, 2009, p. 79). And that's what contributes to the richness of their testimonials and to the credibility and legitimacy of a news item: the perception of their joy, dissatisfaction, outrage or any other emotion towards a particular event. That is the exact reason why the understanding of the role the citizens play in the national news is of great importance.

Along the same lines, it was considered relevant to examine the presence of men and women, notably the kind of visibility given to both genders when the source of information taken into account is the "ordinary citizen". Studies, such as the one by Lopes (2006), show that as a source of information men are the preferred choice, which confirms the great relevance of this analysis, within the Portuguese Public Service.

Herbert Gans (2011) states that, in reference to journalism, despite the improvement in news impartiality standards, there have been reports of a greater sensibility in regard to gender, religious, race, as well as, social biases. Gender inequality is, therefore, still a pressing question in the news sphere.

Men have the tendency to have more prominence in television news in comparison to women. "In the $2 \mathrm{O}^{\text {th }}$ century's last decade, the main weekly news programmes broadcasted by the Portuguese generalist television channels showed clear signs of a strong and well-established social reproduction of male power" (Lopes, 2006, p. 2). In the news, journalists prefer men as sources. Daniel Berkowitz mentions a study by Armstrong in which the author concludes that in news coverage "male sources received more mention and were placed more prominently" (Berkowitz, 2009, p. 110). They discuss ideas, unlike women that are the preferred choice when the focus is on the emotion, which ultimately exposes a society represented by the male gender (Lopes, 2006).

On the whole, according to everything aforementioned, men, until recently, represented a much bigger piece of the citizen's sources of information pie, since "in television men talk about public issues and women about private matters" (Lopes, 2006, p. 8).

\section{MeTHODOLOGY}

In this study, a content analysis of RTP's news programme Jornal da Tarde was performed in order to observe the presence of citizens as sources of information. Since Jornal da Tarde's broadcasts are audiovisual documents, the content analysis was the chosen method due to the nature of the object of study and because, according to Quivy 
and Campenhoudt, "data collected from documents" (Quivy \& Campenhoudt, 2008, p. 204) can be used in different types of analysis, including content analysis.

Television broadcasts were content-analysed after the selection of 3 sample weeks: the last weeks of April (from $27^{\text {th }}$ April to $3^{\text {rd }}$ May), of May (25 th $37^{\text {st }}$ May) and of June $\left(29^{\text {th }}\right.$ June to $5^{\text {th }}$ July). The analysis was performed with the help of RTP's website (RTP Play) that offers an online service which allows people to catch up on past television programmes.

The total duration, the number of news stories and the headline stories were the highlighted aspects in each broadcast. The news analysed in this study are those in which the 'ordinary citizen' takes part as a source of information. However, it is appropriate to point out that there was a concern in analysing only national matters, leaving out any news stories regarding international affairs. Nevertheless, national matters developed in foreign soil were considered for analysis.

To facilitate the intended analysis, two tables were drawn up: the first with the purpose of studying the general aspects of the news stories and the second to study, more specifically, the presence of sources. In the first table, the focus is on the time allotted for each story, the topic, the location of the story and its importance within the newscast (categorized in first headline, second headline, stories in the first and stories in the second half an hour, and those after Jornal da Tarde's commercial break). In the second table, the focus is on the total number of citizens' testimonials in each news story - distinguishing men from women -, the role the sources play and what they speak about.

In this last category of analysis, the intention was to briefly describe the testimonials given by the citizens in the several news stories. Therefore, the various statements were framed into key points, in order to easier understand what the Portuguese citizens talk about when questioned by journalists.

After identifying the roles citizens play in the news, there was the need to take into consideration that, in the same story if there's is more than one testimonial, there's a possibility that those sources have more than just one role. The decision to use this method was taken considering it would be more useful to understand the matter in question: in which situations the citizen is called upon to speak. Regarding vox-pops, for example, the number of passers-by would be predictably high, but that doesn't mean that they (as a category assigned by us) are more prominent (are featured in a greater number of stories) than any other citizen (especially because they generally have less airtime).

To conduct this analysis, many considerations were made in regard to who the 'citizens' are, in this specific context:

- those who relate to Portugal's geographic area;

- those who are individually related to their surroundings, in other words, those that speak for themselves and not in representation of any company, entity or organisation.

\section{DESCRIPTION OF THE RESULTS}

To understand the kind of prioritization given to the news that feature the citizen, they were divided into different categories (as Table 1 shows) according to the newscast 
running order: first headline and second headline topics, as well as those still conveyed in the first half an hour of the programme, stories of the second half an hour and those of the second part, i.e., after the commercial break.

\begin{tabular}{|c|c|}
\hline & TOTAL \\
\hline Number of stories analysed & 657 \\
\hline Number of stories featuring the citizen & 91 \\
\hline Number of participant citizens & 279 (126 men; 153 women) \\
\hline Number of first headline stories featuring the citizen & 9 \\
\hline Number of second headline stories featuring the citizen & 1 \\
\hline $\begin{array}{l}\text { Number of stories featuring the citizen still in the first } \\
\text { half an hour }\end{array}$ & 31 \\
\hline $\begin{array}{l}\text { Number of stories featuring the citizen in the second half } \\
\text { an hour }\end{array}$ & 20 \\
\hline Number of stories featuring the citizen after the break & 30 \\
\hline
\end{tabular}

Table 1: Global results of the 21 Jornal da Tarde's broadcasts analysed

\section{- First week (from $27^{\text {th }}$ April to $3^{\text {rd }}$ May)}

After an analysis of the broadcast's content, it was inferred that, from the 212 news stories that encompassed the seven Jornal da Tarde's programmes examined, 32 incorporated the citizen as a source of information. Each news story ran from the minimum of 1:22 minutes to a maximum 4:42, with an average time of 2:15 minutes. With regard to the newscasts, they were 52:37 to 68:33 minutes in length. One of the most highlighted topics of the week was the TAP-Air Portugal pilots' strike.

These 32 news stories have different standings regarding their importance within Jornal da Tarde: eight of those stories focus on first headline topics and only one on second headline topics. Still in the first thirty minutes of the programme (but not featuring headline topics) there are 13 stories with the citizen as a source and in the second half an hour there are four. Finally, in the second half of the news programme there are six news that fit the criteria.

Individual sources - the "ordinary citizen" - are sources of information, usually, in topics such as strikes, protests, cultural initiatives, crimes, sports, accidents, health, pilgrimage and the economy. It is, however, in protests and strikes that the citizen's participation is more requested. There are 11 news stories about strikes and five of protests. The locations of the events whose stories involve the citizens and their testimonials are, predominantly, centred in Lisbon and in the north of the country, particularly, in the districts of Oporto and Braga.

In the grand total of 32 news stories, 95 citizens were called upon to speak, and are therefore considered news sources. 40 of those testimonials were of the male gender and 55 of the female. There were also three children among those 95 citizens.

During the analysis, it was possible to identify which roles those individual sources play in Jornal da Tarde's news. The most represented are those that act as clients or 
costumers of a product or service, as they are featured in 11 of the 32 stories in question (usually TAP's clients), while six news stories featured protesters. This data analysis showed that in more than half the stories featuring citizens, these present themselves as clients or protesters. Among the identified roles, people who participate in a certain activity, who benefit from an action or endeavour, and who are related are those less significant, considering they are only featured in one story.

Called upon to speak, citizens normally speak about their experiences, feelings and situations they have experienced. In addition, journalists choose to add citizens' testimonials to the aforementioned 32 news stories as there is an interest in knowing the citizen thoughts on a certain subject he is familiar with and express his personal view on matters that concern and affect him. Bearing in mind that a large part of the analysed news stories focus on strikes and protests, many of the testimonials express people's outrage and dissatisfaction in regard to a certain matter or event.

\section{- Second week (from $25^{\text {th }}$ to $31^{\text {st }}$ May)}

In the second sample week, the last of the month of May, 29 news featuring the citizen were identified, among the 223 broadcasted in seven editions of Jornal da Tarde. The duration of the stories oscillated between 1:06 and 3:05 minutes, an average of 2:10 minutes. In regard to the length of the news programme itself the minimum time was of 51:57 minutes and the maximum 62:30. Despite the great diversity of themes highlighted throughout the week, only one was recurrent: the corruption case in FIFA and the organism's elections.

The 29 news stories that feature the citizen as a source of information have different positions in the newscast running order, that is to say, some are more important than other. Only one story fits the first headline category, but none is considered a second headline, 10 stories belong to the first thirty minutes of the programme and five to the second. Finally, in the second half of Jornal da Tarde there are 13 news stories in which the citizen appears as a source.

Generally, citizens come up in topics such as employment, health sport, protests / strikes, accidents, events, education, crime, volunteer work, culture and society. But it is the events category that stands out the most, with a total of seven stories. Sports and health make up - each one - a total of 4 news items with individual sources.

Oporto, Lisbon and Braga are the locations in which most of the stories featuring citizens as sources of information occur. It is important to note that six of the news had no mention in regard to their location and only one was set abroad, specifically in Paris.

The 29 news stories featured a total of 88 citizens. From this total, 40 testimonials were of the male gender - two were children - and 48 of the female gender - one child.

During this second week, as the analysis showed, the role most played by individual sources in Jornal da Tarde was that of audience and merchant/entrepreneur, being each one of these categories a part of four news stories. Each one of the following categories family/friends, users and fans came up in three stories. That makes a grand total of 17 stories out of the 29 identified. 
Throughout this second week, citizens were sources of information since they spoke of problems that concerned them or people close to them; the impact of a new opportunity in their lives - for example, a new job - and about emotions associated to sport events. Besides these topics, indignation, dissatisfaction, as well as various concerns are emphasized. Citizens are, furthermore, called upon to discuss their experiences, their opinions and what motivates them to try different activities.

\section{- Third week (from 29th June to 5th July)}

In the third week, which comprised the last days of June and the beginning of July, among the 222 news stories broadcasted in Jornal da Tarde, 30 stories featured citizens. Their length ranged from 1:14 minutes to 5:01, in an average of 2:14 minutes. With respect to the news programme, the minimum duration was of 52:63 minutes and the maximum of 63:59. This third week there was a wide range of topics discussed in stories that included individual sources, one of the few recurrent one had to do with summer parties. The big highlight of the week was the stalemate/crisis in Greece, that didn't feature any testimonial of an ordinary Portuguese citizen.

In terms of the news running order, in this third week none fitted the criteria of a headline story, that is to say, there were no first headline stories or second headline stories. In the first thirty minutes eight stories were emitted; in the second half an hour, as well as in the second half of the broadcast, there were 11.

This week, the topics about which the citizens speak up are, generically, sports, events, employment, health, culture, protests/strikes, crimes, society, weather forecasts and fires. However, and despite the wide range of those categories, society (with nine stories) and events (with six) are the ones that stand out by featuring the citizen as a source of information. Sports and protests/strikes are the subject of three news items each.

In terms of location, once again the Oporto and Lisbon districts stand out, the first with eight news stories, and the second with five. Note that five of the stories don't have a specific location and that one takes place abroad, in Prague.

From the 96 citizens featured in the examined stories 46 are men - two boys -, and 50 are women - with two girls. It should also be noted that in the total of men there are two anonymous sources, a boy and a man, and in the total of women also two, a girl and a woman.

In regard to the roles played by the citizens, the ones that stand out are audience/ participants and employee/ex-employee, with eight and six stories, respectively. Victims and family/friends are also relevant, with four news pieces each. Merchants/entrepreneurs, during this week, only featured three stories, as well as passers-by.

And, this week, what do the citizens talk about when asked to intervene? They speak about their emotions and life experiences about the topic discussed, and they give their opinions. Furthermore, similarly to the previous weeks, the testimonials emphasize their dissatisfaction and concern over problems that affect them. 


\section{DiSCUSSION OF THE RESULTS}

According to the results previously presented and described, only about $14 \%$ of the total of news stories that made up the 21 Jornal da Tarde's broadcasts analysed featured citizens as sources of information. That is to say, only a minority of the broadcasted news during every programme turned to the 'ordinary citizen' to illustrate and improve on its content. This can be explained by the fact that the citizens' contribution may not be pertinent to the type of approach taken in many stories which look for more institutionalized perspectives. Furthermore, in every programme, there were times when individuals with a given position in a given organisation intervened. This data supports what has already been reported by many scientific studies on the relationships between journalists and their sources: official and institutional sources are predominant (Berkowitz, 2009; Gans, 2008).

The length of the sampled news stories fall within the usual duration of TV news: around 2:18 minutes. There isn't, therefore, a difference between stories featuring citizens and those which don't. Yet, there is an aspect deserving of mention: 41 news items, about $45 \%$ of the 91 in which the citizen participates, are broadcasted in the first thirty minutes of Jornal da Tarde (already including first headline and second headline stories). Considering that the news programme usually lasts a little more than an hour, these figures show that less than half the news with citizen participation is broadcasted within the first thirty minutes, leaving the remaining $55 \%$ to the second half of the programme.

It is, however, important to point out that throughout the first sample week $\left(27^{\text {th }}\right.$ April to $3^{\text {rd }}$ May), there was a strike by pilots working for TAP-Air Portugal which led to many live coverages from the Portuguese airports. There was, in this case, an interest in the citizens' point of view, by showing the inconveniences of the situation or their opinion on the matter. The strike was a trending topic during almost the entire week, which led to a bigger presence of citizens in the news. Not taking into account this first week, only $19 \%$ of the total of news stories featuring citizens (11 out of 59 ) were broadcasted in the first thirty minutes of Jornal da Tarde.

Another relevant aspect of this investigation is to understand in what type of situations the citizen is given voice to and when he has his own airtime in public service news broadcasts. Thus, it has been found that the 'ordinary citizen' particularly speaks when he is the face or protagonist of the situation that originates the news, as in the case of protests, or when his life is somewhat greatly affected by the referred situation, for example, in the case of TAP clients whose lives were hampered by the pilots' strike. This happens possibly because those are situations to which the other citizens can relate and that can, somehow, enlighten the viewers on a story that affects, in a smaller or bigger scale, the country's situation.

Moreover, in most of the news examined, the citizens' testimonials have the utmost importance when trying to understand the situation in question, what is happening or what has already happened. Once again it is clear that the citizens' testimonials are useful, first and foremost, to report an experience that may have affected many of the programme's viewers. Moreover, the fact that there are many stories about protests or strikes featuring citizens' testimonials, mainly in the first sample week, corroborates this. 
In cases such as popular festivities or light topics, the citizen is asked to voice his opinion, usually in the vox-pop format, although without a lot of airtime. This is something that, normally, increases the number of participants in one single news item. 'Audience or participant' is, therefore, another big role given to the citizen-source. This was the category that most stood out in the last two weeks analysed - then without the coverage of the highly newsworthy TAP pilots' strike.

Taking a look at the locations where the citizen's presence is more noticeable, something stands out: Lisbon, Oporto and Braga (the last in a much smaller scale) are the districts where people's opinion are more sought after and where there are more news stories featuring citizens. Those are coastal and well-populated regions, as well as geographically closer to the RTP's newsrooms in Lisbon and Oporto. It is evident, once again, that the media prefer more central regions, putting aside less populated areas. Actually, it can't be said that in these areas there are news in which the citizen doesn't take part (as the data collected doesn't allow for that kind of analysis); but one can point out that those who live in these regions aren't the ones often called upon to voice their opinions (in the vox-pop format).

Another interesting aspect concerns the number of men and women featured in RTP's news broadcasts. Women appear more often, which seems to show a turnaround in what, until recently, was reported by many scientific researches. It appears we are heading towards equality, as there isn't a big discrepancy between the number of female and male testimonials. There is even no apparent reason that may justify this situation: there are no news that need female testimonials alone. Yet, it is interesting to see that, in fact, when in search of emotions, journalists choose women.

In the news featuring citizens as sources, their opinions are, usually, shared by almost everyone. Dissatisfaction is, often, the primary feeling, much due to the type of stories the citizens are supposed to comment on. Thus, and essentially in terms of strikes and protests, there is a general opinion, usually of anger, that expresses the damages caused or what is demanded. In cases such as popular festivities or events, the citizen plays the part of audience or participant, giving a more personal testimonial. After all, since they are the protagonists of the story, one can say that the citizens are 'specialists' in lighter and softer topics. In these particular cases, their opinion is usually a positive one.

\section{Conclusion}

With an analysis focused in three separate weeks, it is clear that the presence of the citizen and the roles he plays are not constant and are clearly dependent on the type of events portrayed in the news story. By looking at the first sample week, one can see that the citizen was a lot more important and took a leading position, whereas the same cannot be said of the other two weeks.

Protesters or clients of a service (especially in the case of TAP) are some of the roles played by the individual sources in RTP's Jornal da Tarde. These sources, almost invariably, present their personal experience on a certain subject and portray emotions, more 
often than not of dissatisfaction on that same subject. This means that, usually, when there are strikes or protests, the citizen is asked to speak.

In contrast, in case of parties or events, the citizen, as a member of the audience and a participant, is also a recurring source of information by being asked to give his perspective, usually showing contentment and satisfaction. However, aside from these types of cases, the citizen is usually called upon to speak about more negative topics (crimes, protests, fires, accidents ...).

Women appear to be the most requested gender, contrary to what, until recently, seemed to be the norm. Yet, the truth is that women were always considered priority sources when the focus is on emotion. For that matter, the idea that journalists prefer female testimonials when showing joy, sorrow or anger is corroborated.

Big cities continue to be in the centre of the journalist's work, consequently, limiting the possibility of participation to those who don't live in those areas.

Therefore, and returning to the question that was the starting point of this study (what is the extent of the citizen's presence in RTP's Jornal da Tarde and what role does he play in it?), it can be asserted that the citizen still hasn't got a very strong presence as a source of information, considering that he was only featured, at least once, in $14 \%$ of the news stories analysed. Additionally, the citizen participates whenever he is involved in the situation, whether willingly or not. His opinion about other type of topics of equal importance to public discussion (policy matters, education, health or justice) is not normally requested.

Therefore, it can be said that the citizen plays the role of news "illustrator", not being usually the protagonist of the situation he speaks of, despite being, nevertheless, involved in it. He is neither the key nor the central element of the news story nor is he the one that opens the story. The situations in which he is involved in end up determining the importance he has in the story and they are, truly, the reason why the journalists "take to the streets". Thus, and considering that the participation is an essential factor in the definition of what the Public Service should be and in its mission towards society, the citizen, in the television news domain, still has a secondary role and he is given little centrality in the news production process.

\section{BIBLIOGRAPHIC REFERENCES}

Berkowitz, D. (2009). Reporters and their sources. In K. Wahl-Jogersen \& T. Hanitzsch (Eds.), The handbook of journalism (pp. 102-115). Nova lorque/Londres: Routledge.

Correia, J. C. (2012). A participação como desafio à profissão jornalística. In J. C. Correia (Ed.) Ágora - Jornalismo de Proximidade: Limites, Desafios e Oportunidades (pp. 5568). Covilhã: Livros Labcom (eBook). Retrieved from https://www.researchgate.net/ publication/265738213_A_participacao_como_desafio_a_profissao_jornalistica

De Keyser, J., Rayemaeckers, K. \& Paulussen, S. (2011). Are citizens becoming sources? A look into the professional contacts of Flemish journalists. In B. Franklin \& M. Carlson (Eds.), Journalists, Sources and Credibility: New Perspectives (pp. 139-151). Nova lorque/Londres: Routledge.

Gans, H. (2008). Deciding what news is: the organization of story selection. In H. Tumber (Ed.), Journalism critical concepts in media and cultural studies (pp. 235-248), Nova lorque/ Londres: Routledge. 
Gans, H. (2011). Multiperspectival news revisited: Journalism and representative democracy. Journalism, 12(1), $3-13$.

Lopes, F. (2000). As fontes, os jornalistas e as leis. Comunicação e Sociedade, 1-2, 339-349. Retrieved from http://repositorium.sdum.uminho.pt/bitstream/1822/5511/1/CS_vol2_flopes_p339-349.pdf

Lopes, F. (2006). Homens públicos, mulheres privadas - a presença da mulher na informação televisiva. Retrieved from http://www.bocc.ubi.pt/pag/lopes-felisbela-homens-publicos-mulheres-privadas-2007. pdf

Lopes, F., Neto, I. \& Ribeiro, F. (2014). Letting people talk in media? Portrait and problems of citizens' participation in audience discussion programmes. In J. Pérez Tornero (Ed.), Media literacy and intercultural dialogue: strategies, debates and good practices (pp. 118-128). Retrieved from http:// repositorium.sdum.uminho.pt/bitstream/1822/29604/1/FL_IV_FR_Media.pdf

Pantti, M. \& Husslage, K. (2009). Ordinary people and emotional expression in Dutch public service news. Javnost - The Public: Journal of the European Institute for Communication and Culture, 16(2), 77-94. Doi: $10.1080 / 13183222.2009 .11009005$

Pinto, M. (2000). Fontes jornalísticas: contributos para o mapeamento de campo. Comunicação e Sociedade, 1-2, 277-294. Retrieved from http://repositorium.sdum.uminho.pt/bitstream/1822/5512/1/CS_vol2_ mpinto_p277-294.pdf

Pinto, M. (2005). Pensar e projetar o serviço público com a participação do público. Comunicação e Sociedade, 1, 41-59.

Quivy, R. \& Campenhoudt, L. V. (2008). Manual de Investigação em Ciências Sociais. Lisboa: Gradiva.

Schmitz, A. (2011). Classificação das fontes de notícias. Retrieved from http://bocc.ubi.pt/pag/schmitz-aldoclassificacao-das-fontes-de-noticias.pdf

Traquina, N. (2002). O que é Jornalismo. Lisboa: Quimera.

\section{OTHER REFERENCES}

Código do Processo Penal [Code of Criminal Procedure]. Retrieved from http://www.pgdlisboa.pt/leis/lei_ mostra_articulado.php?artigo_id=199A0135\&nid=199\&tabela=leis\&pagina=1\&ficha=1\&nversao=\#artigo

Contrato de Concessão do Serviço Público de Rádio e de Televisão . Retrieved from http://www.rtp.pt/ wportal/grupo/governodasociedade/contrato_concessao_pdf.php

Estatuto do Jornalista. Retrieved from http://www.erc.pt/documentos/lei199.pdf

Lei da Televisão (Lei n²7/2007) de 30 de julho, República Portuguesa. Retrieved from:http://www.erc.pt/ documentos/Lei_Televisao_2007.pdf

\section{BIOGRAPHICAL NOTES}

Inês Mendes holds a Masters in Communication Sciences from Universidade do Minho. Has been involved in academic journalism through ComUM.

E-mail: inesgmendes27@gmail.com

Departamento de Ciências da Comunicação - ICS 
Universidade do Minho

Campus de Gualtar

4710-057 Braga, Portugal

Raquel Martins

Holding a Masters in Communication Sciences from Universidade do Minho. Has been involved in academic journalism, namely by being the Editor of ComUM.

E-mail: anaraquelmartins23@gmail.com

Departamento de Ciências da Comunicação - ICS

Universidade do Minho

Campus de Gualtar

4710-057 Braga, Portugal

* Submitted: 13-03-2016

* Accepted: 14-04-2016 